\title{
Short Term Impacts of Amending Calcareous and Non-Calcareous Sandy Soils with Organic Amendments and Their Extracts: Effects on Soil Biota, Soil Physical and Chemical Characteristics
}

Ihab M. Farid ${ }^{1}$, Mohamed A. El-Ghozoli ${ }^{2}$, Mohamed H.H. Abbas ${ }^{1 *}$, Hassan H. Abbas ${ }^{1}$, Ibrahim Mohamed ${ }^{1}$ Elsayed, Dalia S. El-Atrony ${ }^{1,2}$

${ }^{1}$ Soils and Water Department, Faculty of Agriculture, Benha University (Egypt)

${ }^{2}$ Agricultural Microbiology department, Soils, Water and Environment Research Institute, Agricultural

Research Center (ARC)

*Corresponding e-mail: mohamed.abbas@fagr.bu.edu.eg

\begin{abstract}
In arid and semi-arid soils, organic residues undergo rapid degradation and their consequences are positive on both soils and living biota. Probably, humic substances, which are organics that resist biodegradation, can bring further positive consequences on soil characteristics and biota living therein on the short run. To investigate this hypothesis, a pot experiment was conducted using two sandy (calcareous vs non calcareous) soils amended with organic substances (compost and biogas manure) and their extracts (humic acid (HA) and fulvic acid (FA)). Applications of compost and biogas manure were based on a constant $\mathrm{N}$-input, equivalent to $36 \mathrm{~kg} \mathrm{~N} \mathrm{ha}^{-1}$, while in case of organic extract treatments, soils received supplementary doses of ammonium sulphate $(20.5 \% \mathrm{~N})$ to raise $\mathrm{N}$-content in soils to the recommended dose. Control treatments, that received a full dose of $\mathrm{N}$ as ammonium sulphate, were also considered for data comparison. The experimental design was a complete randomized one. All pots were planted with faba bean seeds and incubated under the greenhouse conditions for 80 days. Results indicated that organic applications stimulated total counts of soil bacteria and fungi by the end of the experimental period. These organic treatments increased significantly values of soil EC and CEC. On the other hand, their impacts on soil bulk density and $\mathrm{pH}$ were not detectable. Further significant improvements in soil chemical characteristics and total bacterial and fungal counts were attained owing to application of the organic extracts (HA or FA) as compared to their sources; yet, organic manures retained higher residual organic carbon (ROC) than their extracts did. In conclusion, application of organic amendments and especially their extracts recorded positive impacts on soil characteristics on the short run; yet, improvements in soil bulk density are mostly related to long term microbial activities.
\end{abstract}

Key words: sandy soils; calcareous sandy soil; humic substances; compost; biogas; soil biota; soil characteristics.

\section{Introduction}

Plant residues are important sources of soil organic carbon (SOC) and nutrients that are needed for soil biota (Liu et al., 2009) and plant growth (Abbas et al., 2011; Farid et al., 2014; Farid et al., 2018; Zhang et al., 2020). These residues may also lessen soil degradation (Diacono and Montemurro, 2011). For this reason, recycling organic amendments is an important protocol to increase soil health (Urra et al., 2019) and sustainability (Scotti et al., 2015). It is worthy to mention that the effects of soil organic amendments are detectable on soil characteristics (Hao et al., 2008; Wei et al., 2016; Elcossy et al., 2020), yet these effects might not be noticeable on some soil physical properties, particularly bulk density on the short run (Brye et al., 2005). On the other hand, the degradation of organic amendments in arid and semi-arid soils seemed to be high (Abdelhafez et al., 2018; Guo et al., 2019), because of the warm climate dominating in such an arid region which consequently accelerates the decomposition of the organic amendments (Thakur et al., 2018), even the relatively resistant organic pools (Fang et al., 2005). Moreover, soil fungal activities were stimulated due to the organic applicants on the short run and such increases recover soil quality and fertility (Tayyab et al., 2019). Thus, we believe that amending poor structural soils of low fertility with organic amendments might result in considerable improvements in soil characteristics and the biota living therein on the short term.

Humic substances (HS) are of special concern in this study because they are the main reservoirs of $\mathrm{C}$ in the biosphere, comprising up to $70 \%$ of soil organic matter (SOM) (Grinhut et al., 2007). It involves humic acid, fulvic acids (Nardi $\boldsymbol{e t}$ al., 2017) and humin (Lipczynska-Kochany, 2018A). These substances coat soil minerals and therefore improve their characteristics (Ghabbour et al., 2004). Moreover, HS are resistant against biodegradation (Lipczynska-Kochany, 2018B) and can be retained in soil for longer time periods (vs organic amendments) (Gerke, 2018). The presence of $\mathrm{Ca}$ 
which is the dominant cation in calcareous soils may affect sorption of humic substances on clay minerals (Majzik and Tombácz, 2007) and this may probably increase/decrease the positive effects of the applied amendments to ameliorate calcareous soils.

The current study investigates the potential impacts of amending soils with different organic amendments i.e. compost, biogas manure as well as humic and fulvic acids extracted from these amendments beside of combinations of the aforementioned amendments, on stimulating soil biota; beside of improving soil physical and chemical characteristics. This study was conducted under the controlled greenhouse conditions to monitor precisely such effects while considering the following two hypotheses.

H1: Application of organic residues stimulates total counts of soil biota (bacteria and fungi) in the sandy soils whether they were non-calcareous or calcareous and this may increase degradation of the organic matter and consequently lessen considerably residual organic carbon by the end of the growing season.

$\mathrm{H} 2$ : These applications significantly improve soil physical and chemical characteristics on the short run.

\section{Materials and Methods}

Surface soil samples were collected from two areas to represent a non-calcareous sandy soil from El Dair (Qalubia Governorate, Egypt) and a calcareous sandy one from El-Nubaria (Beheira Governorate, Egypt). Soil samples were air dried, finely ground to pass through a $2 \mathrm{~mm}$ sieve then analyzed for their particle size distribution and chemical properties according to Klute (1986) and Sparks et al. (1996), respectively Results of analyses are presented in Table 1.

Table 1.Particle size distribution and chemical properties of the investigated soils.

\begin{tabular}{|c|c|c|}
\hline Property & $\begin{array}{c}\text { El Dair (sandy } \\
\text { non-calcareous) soil }\end{array}$ & $\begin{array}{l}\text { Nubaria (sandy } \\
\text { calcareous ) soil }\end{array}$ \\
\hline \multicolumn{3}{|l|}{ Particle size distribution \% } \\
\hline Sand & 91.8 & 94.9 \\
\hline Silt & 2.2 & 2.3 \\
\hline Clay & 6.0 & 2.8 \\
\hline Textural class & Sand & Sand \\
\hline \multicolumn{3}{|c|}{ Soluble Cations $\left(\mathrm{mmol}_{\mathrm{c}} \mathbf{L}^{-1}\right)$} \\
\hline $\mathrm{Ca}^{2+}$ & 6.50 & 22.8 \\
\hline $\mathrm{Mg}^{2+}$ & 3.75 & 17.9 \\
\hline $\mathrm{Na}^{+}$ & 3.14 & 9.80 \\
\hline $\mathbf{K}^{+}$ & 0.61 & 0.50 \\
\hline \multicolumn{3}{|c|}{ Soluble anions $\left(\operatorname{mmol}_{\mathrm{c}} \mathrm{L}^{-1}\right)$} \\
\hline $\mathrm{CO}_{3}^{--}$ & 0.00 & 0.00 \\
\hline $\mathrm{HCO}_{3}{ }^{-}$ & 2.50 & 2.00 \\
\hline $\mathrm{Cl}^{-}$ & 2.50 & 25.00 \\
\hline $\mathrm{SO}_{4}^{--}$ & 9.00 & 24.00 \\
\hline $\mathrm{pH}^{*}$ & 7.65 & 8.2 \\
\hline $\mathrm{EC}^{* *}, \mathrm{dS} \mathrm{m} \mathrm{m}^{-1}$ & 1.4 & 5.0 \\
\hline Soil organic matter, $\mathrm{g} \mathrm{kg}^{-1}$ & 3.3 & 7.1 \\
\hline CEC, cmolc kg-1 & 13.5 & 13.9 \\
\hline $\mathrm{CaCO}_{3}, \mathrm{~g} \mathrm{~kg}^{-1}$ & 15 & 223 \\
\hline Bulk density, $\mathrm{Mg} \mathrm{m}^{-3}$ & 1.6 & 1.4 \\
\hline
\end{tabular}

Soil $\mathrm{pH}$ was determined in a soil: water suspension (1:2.5) and soil EC was determined in a soil paste extract

\section{Organic amendment sources:}

Matured compost was prepared from both rice straw $(50 \mathrm{~kg})$ and farmyard manure $(30 \mathrm{~kg})$ supplemented with elemental sulfur $(4 \mathrm{~kg})$, rock phosphate $(8 \mathrm{~kg})$, zinc sulfate $(0.4 \mathrm{~kg})$ and urea $(2$ $\mathrm{kg}$ ). This mixture was incubated under the aerobic heap conditions for three months. Biogas manure was obtained from the Training Center for Recycling of Agricultural Residues at Moshtohor (TCRAR), Soils, Water and Environment Research, Institute, Agricultural Research Center (Giza, Egypt). Physical and chemical characteristics of these amendments are presented in Table 2. 
Table 2. Physical, chemical and biological properties of the compost and biogas manure under study.

\begin{tabular}{|c|c|c|}
\hline Property & Compost & Biogas manure \\
\hline Density $\mathrm{Mg} / \mathrm{m}^{3}$ & 0.72 & 0.65 \\
\hline Moisture content $\%$ & 23.70 & 9.30 \\
\hline pH (1:10 extract) & 7.58 & 7.83 \\
\hline $\mathrm{EC} \mathrm{dSm}^{-1}(1: 10$ extract $)$ & 4.17 & 3.15 \\
\hline Total-N \% & 28.3 & 26.0 \\
\hline Organic carbon $\left(\mathrm{g} \mathrm{kg}^{-1}\right)$ & 494.60 & 514.0 \\
\hline $\mathrm{C} / \mathrm{N}$ ratio & $17.5: 1$ & 19.8:1 \\
\hline Total bacterial count $\mathrm{cfu} / \mathrm{gx} 10^{7}$ & 7.3 & 5.80 \\
\hline Total fungal count $\mathrm{cfu} / \mathrm{gx} 10^{5}$ & 3.90 & 4.20 \\
\hline
\end{tabular}

Note: cfu. Indicates colony forming unit

\section{Seeds source}

Seeds of faba bean (Vicia faba, c.v Giza-2) were obtained from the Field Crops Research Institute, Agricultural Research Center, Giza, Egypt. Rhizobium leguminosarium (ICARDA441) inoculum was obtained from Biofertilizers Production Unit, Soils, Water and Environment Res. Inst. Agric. Res. Center, Giza, Egypt. Faba been seeds were successively washed with water, air dried, then soaked in cell suspension of rhizobium Sp. $(1 \mathrm{~mL}$ contains about $8.4 \times 10^{7}$ viable cell) for $30 \mathrm{~min}$. Arabic gum (16\%) was then added as an adhesive agent prior to inoculation; afterwards, these seeds were air dried for an hour before sowing.

\section{Extraction and purification of humic and fulvic acids}

Extraction of humic substances was carried out as outlined by Sanchez - Monedero et al. (2002). Briefly, humic substances were extracted from compost and biogas manures after being treated with $0.5 \mathrm{~N} \mathrm{KOH}$ solution. The supernatant was acidified by $\mathrm{HCl}(2 \mathrm{~N})$ to reach a $\mathrm{pH}$ value of 2.0 then left overnight. Precipitates, conventionally known as humic acid (HA), were separated from the soluble fulvic acids by centrifugation at $6000 \mathrm{rpm}$ for 15 minutes. Afterwards, HA precipitate was washed several times with $0.05 \mathrm{~N} \mathrm{H}_{2} \mathrm{SO}_{4}$ until the filtrate became colorless; thereafter, this precipitate was purified with electrodialysis and then air dried (Chen and Schnitzer, 1978).

Purification of fulvic acid (the supernatant from the previous step) was carried out according to Kononova (1966) and Susilawati et al.(2007) as follows: fulvic acid solution was passed through activated charcoal followed by elution of the charcoal. Then, the solution was concentrated, transferred to membrane filter and elctrodialysed until the solution became free from $\mathrm{Cl}$.

Elemental composition of the used amendments was estimated using gas chromatography on a Hewlett - Packard 185 Analytical Center, Faculty of Science, Cairo University. Oxygen was then calculated by subtraction of the percentages of $\mathrm{C}, \mathrm{H}$, $\mathrm{N}$ and $\mathrm{S} \%$ from 100 and the results are presented in Table 3.

Table 3. Chemical composition of the investigated amendments (compost and biogas manures) and their extracted humic (HA) and fulvic (FA) acids.

\begin{tabular}{lcccccc}
\hline & \multicolumn{3}{c}{ Compost } & \multicolumn{3}{c}{ Biogas } \\
\cline { 2 - 7 } Character & manure & HA & FA & manure & HA & FA \\
\hline C\% & 49.46 & 50.71 & 50.4 & 51.4 & 49.9 & 46 \\
N\% & 2.83 & 3.1 & 2.72 & 2.60 & 2.85 & 2.75 \\
H\% & 1.45 & 1.93 & 1.84 & 2.12 & 2.10 & 3.89 \\
$\mathbf{S \%}$ & 3.76 & 3.96 & 3.14 & 3.68 & 4.15 & 3.46 \\
$\mathbf{O}_{\mathbf{2} \%}$ & 42.5 & 40.3 & 41.9 & 40.2 & 41 & 43.9 \\
C/N ratio & 17.5 & 16.4 & 18.5 & 19.8 & 17.5 & 16.7 \\
C/H ratio & 34.1 & 26.3 & 27.4 & 24.2 & 23.8 & 13.3 \\
C/O ratio & 1.2 & 1.3 & 1.2 & 1.3 & 1.2 & 1.05 \\
O/H ratio & 29.3 & 20.9 & 22.8 & 19 & 19.5 & 11.3 \\
N/H ratio & 1.95 & 1.6 & 1.5 & 1.3 & 1.4 & 0.4 \\
\hline
\end{tabular}




\section{The greenhouse experiment.}

A pot experiment was conducted on November 2019 under the greenhouse conditions at the Training Center for Recycling of Agricultural Residues at Moshtohor (TCRAR), Soils, water and Environment Research Institute, Agricultural Research Center (ARC). The experimental design was a complete randomized one comprising three factors, in triplicates: two soil types (a calcareous soil and a non-calcareous sandy one), two organic resources (biogas and compost beside of their extracts i.e.HA and FA). The treatments of the study were no organic additions $\left(\mathrm{T}_{0}\right), 100 \%$ organic-N (org-N) to satisfy the recommended $\mathrm{N}$-dose $\left(36 \mathrm{~kg} \mathrm{~N}^{-1}, \mathrm{~T}_{1}\right), 50 \%$ org +50\% inorganic-N $\left(\mathrm{T}_{2}\right), 100 \%$ HA $\left(74 \mathrm{~L} \mathrm{ha}^{-1}, \mathrm{~T}_{3}\right)$, $50 \%$ HA $\left(\mathrm{T}_{4}\right), 100 \% \mathrm{FA}\left(74 \mathrm{~L} \mathrm{ha}^{-1}, \mathrm{~T}_{5}\right)$ and $50 \% \mathrm{FA}$ $\left(T_{6}\right)$. In humic and fulvic treatments $\left(T_{3}-T_{6}\right)$, soils received supplementary doses of ammonium sulphate $(20.5 \% \mathrm{~N})$ to raise $\mathrm{N}$-content to the recommended dose (for more details, see Table 4). Soil portions (equivalent to $2 \mathrm{~kg}$ ) were mixed thoroughly with one of the abovementioned treatments and then received calcium superphosphate $(\mathbf{8 . 5 \%} \mathbf{P})$ and potassium sulphate $(\mathbf{4 8 \%} \mathbf{K})$ (after considering their contents in

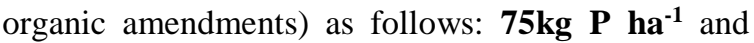
48kg K ha-1, respectively. Soils were then packed uniformly in plastic pots of $21 \mathrm{~cm}$ diameter and 16 $\mathrm{cm}$ height to maintain constant bulk densities of 1.60 and $1.44 \mathrm{Mg} \mathrm{m}^{-3}$ for non- calcareous and calcareous soils, respectively. Five bean seeds were sown in each pot and soils were irrigated with deionized water to bring soil moisture content to the field capacity; afterwards, irrigation was carried out every 5-7 days.

Two weeks after planting, seedlings of faba beans were thinned to 4 ones per pot. After 80 days of planting, soils were sampled and the following characteristics were determined: $\mathrm{pH}, \mathrm{EC}$, residual organic carbon (ROC), CEC and soil bulk density according to the standard methods of Sparks $\boldsymbol{e t}$ al. (1996) and Klute (1986). Determination of the total counts of bacteria and fungi in soil samples were determined according to Reinhold $\boldsymbol{e t}$ al.(1985) as follows: one $\mathrm{mL}$ of the soil suspension $(1: 5, \mathrm{w}: \mathrm{v})$ was poured on agar media in Petri dishes and then incubated for 7 days at $30^{\circ} \mathrm{C}$. Afterwards, total bacterial and fungal counts were assessed.

Table 4. Details regarding organic treatments and their extracts.

\begin{tabular}{|c|c|c|}
\hline \multirow{2}{*}{$\begin{array}{l}\text { Factor one } \\
\text { (Soil type, S) }\end{array}$} & Factor two & \multirow{2}{*}{$\begin{array}{l}\text { Factor three } \\
\text { Organic treatments }\end{array}$} \\
\hline & $\begin{array}{l}\text { (The organic amendment } \\
\text { source) }\end{array}$ & \\
\hline A non-calcareous sandy soil, $S_{1}$ & Biogas, $\mathrm{O}_{1}$ & No organic amendment, $T_{0}$ \\
\hline A calcareous sandy soil, $S_{2}$ & Compost, $\mathrm{O}_{2}$ & $100 \%$ org-N, $\mathrm{T}_{1}$ \\
\hline & & $50 \%$ inorg-N+50\% org, $\mathrm{T}_{2}$ \\
\hline & & $100 \% \mathrm{HA}, \mathrm{T}_{3}$ \\
\hline & & $50 \% \mathrm{HA}, \mathrm{T}_{4}$ \\
\hline & & $100 \% \mathrm{FA}, \mathrm{T}_{5}$ \\
\hline & & $50 \% \mathrm{FA}, \mathrm{T}_{6}$ \\
\hline
\end{tabular}

\section{Data Analyses}

Data were statistically analyzed using PASW statistical software 18 through analysis of variance (ANOVA) and Dunken's test at 0.05 probability level. Graphs were plotted using SigmaPlot 10 software.

\section{Results and Discussion}

Effect of organic amendments and their extracts on soil bulk density

Analysis of variance revealed that soil bulk density was not significantly affected by either the source of the organic amendment $(\mathrm{F}=0.071$, $P=0.791)$, the type of the soil $(\mathrm{F}=2.631, P-0.110)$ or even the organic treatment $(\mathrm{F}=1.017, P-0.424)$ on the short run. Moreover, interactions among these three factors were of no significant effect on soil bulk density $(\mathrm{F}=0.328, P=0.920)$. These results contradict the findings which indicated that organic amendments find their way between soil particles (Tobiašová et al., 2016), then trapped in small pores forming aggregates (Balesdent $\boldsymbol{e t}$ al., 2000)to be partially protected against biodegradation (Goebel $\boldsymbol{e t}$ al., 2009), while improved soil aggregation (Farid $\boldsymbol{e t}$ al., 2014; Farid et al., 2018; Mohamed et al., 2021). The other assumption presented by Abdelhafez et al. (2018) is more sensible which indicate that more stable organic components are built up in soil on the long run. These organic components may account for improving soil structure (Elcossy et al., 2020). 
Table 5. Bulk density of the sandy non-calcareous and calcareous soils under study as affected by the application of organic and mineral fertilizers, either solely or in different combinations (Treatments from $\mathrm{T}_{0}$ to $\mathrm{T}_{6}$ : see Table 4 )

\begin{tabular}{|c|c|c|c|c|}
\hline & \multicolumn{2}{|c|}{ Non-calcareous soil } & \multicolumn{2}{|c|}{ Calcareous soil } \\
\hline \multirow[t]{2}{*}{ Treatment } & Biogas manure & Compost & Biogas manure & Compost \\
\hline & \multicolumn{4}{|c|}{ Soil bulk density, $\mathrm{Mg} \mathrm{m}^{-3}$} \\
\hline $\mathrm{T}_{0}$ & $1.61 \pm 0.25^{\mathrm{a}}$ & $1.61 \pm 0.25^{\mathrm{a}}$ & $1.42 \pm 0.37^{\mathrm{a}}$ & $1.42 \pm 0.38^{\mathrm{a}}$ \\
\hline $\mathrm{T}_{1}$ & $1.42 \pm 0.03^{\mathrm{a}}$ & $1.43 \pm 0.24^{\mathrm{a}}$ & $1.37 \pm 0.5^{\mathrm{a}}$ & $1.25 \pm 0.37^{\mathrm{a}}$ \\
\hline $\mathrm{T}_{2}$ & $1.40 \pm 0.18^{\mathrm{a}}$ & $1.59 \pm 0.25^{\mathrm{a}}$ & $1.31 \pm 0.23^{\mathrm{a}}$ & $1.36 \pm 0.26^{\mathrm{a}}$ \\
\hline $\mathrm{T}_{3}$ & $1.25 \pm 0.03^{\mathrm{a}}$ & $1.40 \pm 0.07^{\mathrm{a}}$ & $1.43 \pm 0.05^{\mathrm{a}}$ & $1.18 \pm 0.02^{\mathrm{a}}$ \\
\hline $\mathrm{T}_{4}$ & $1.31 \pm 0.44^{\mathrm{a}}$ & $1.34 \pm 0.29^{a}$ & $1.37 \pm 0.18^{\mathrm{a}}$ & $1.38 \pm 0.18^{\mathrm{a}}$ \\
\hline $\mathrm{T}_{5}$ & $1.54 \pm 0.13^{\mathrm{a}}$ & $1.51 \pm 0.06^{\mathrm{a}}$ & $1.49 \pm 0.05^{\mathrm{a}}$ & $1.34 \pm 0.02^{\mathrm{a}}$ \\
\hline $\mathrm{T}_{6}$ & $1.25 \pm 0.06^{\mathrm{a}}$ & $1.40 \pm 0.03 \mathrm{a}$ & $1.43 \pm 0.46^{\mathrm{a}}$ & $1.18 \pm 0.25^{\mathrm{a}}$ \\
\hline
\end{tabular}

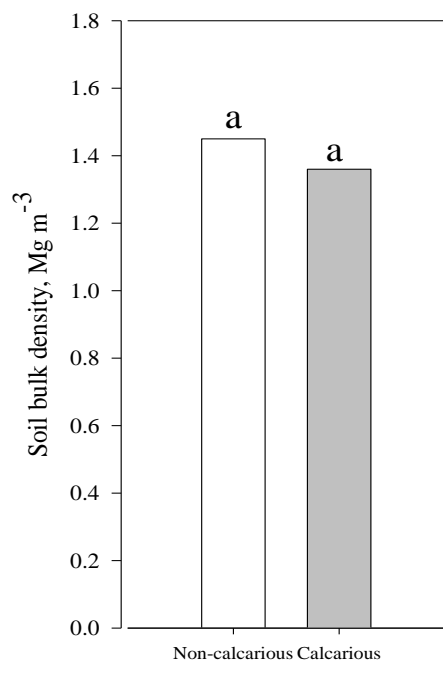

Soil Type

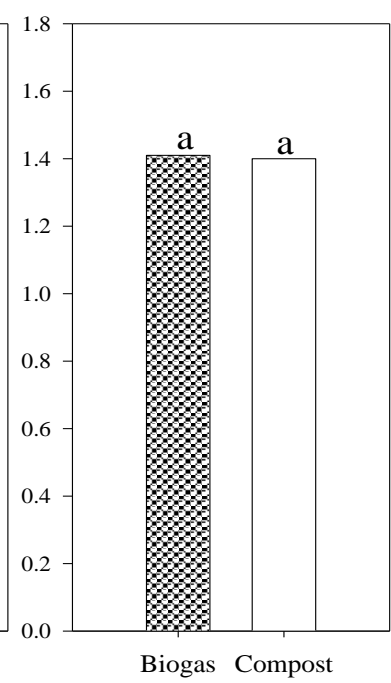

Organic source

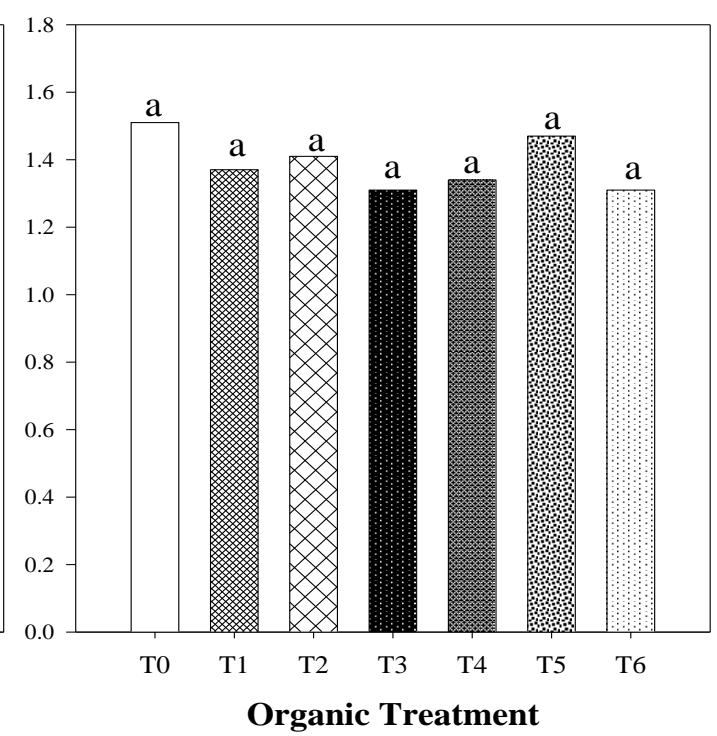

Fig. 1. Grand means of bulk density of the sandy soils under investigation as affected by organic and mineral-N fertilizers, applied either solely or in different combinations (Treatments from $\mathrm{T}_{0}$ to $\mathrm{T}_{6}$ : see Table 4).

Effect of organic amendments and their extracts on soil chemical characteristics:

Effect on the residual organic carbon (ROC)

Residual organic carbon significantly increased in the investigated soils owing to the application of the organic treatments $(\mathrm{F}=68.041, P<0.001)$ with no significant variations between the two sources of organic amendments $(F=0.518, P=0.475)$. Similar results indicated that organic applications significantly increased the residual soil organic carbon (Mahmood et al., 2017). These residues are important aspects of sustainable agriculture (Kumari et $\boldsymbol{a l} ., 2018$ ) because they improve soil physical and chemical characteristics, especially in soils of arid and semi-arid regions (Hemmat $\boldsymbol{e t}$ al., 2010). The obtained results reveal that the application of organic manures (compost or biogas) reocrded the highest increases in the residual soil organic carbon, whose values exceeded those attained due to their extracts (more resistant organic components). Moreover, the recorded values exceeded the initial ones of the soils (1.914 $\mathrm{g} \mathrm{C} \mathrm{kg}^{-1}$ in the non-calcareous soil and $4.118 \mathrm{~g}$ $\mathrm{C} \mathrm{kg}^{-1}$ in the calcareous soil) plus the amended $\mathrm{C}$ amounts through organic applications i.e. $\approx 0.264 \mathrm{~g} \mathrm{C}$ $\mathrm{kg}^{-1}$ for compost and $\approx 0.299 \mathrm{~g} \mathrm{C} \mathrm{kg}^{-1}$ for biogas manure. The reasonable explanation for such increases is that these amendments enriched soils with organic substrates that are needed for soil biota (Blankinship and Schimel, 2018); accordingly soil health improved considerably (Williams et al., 2020). This may increase the consequently the beneficial symbiosis between soil biota and the grown plants (Majeed et al., 2018). In such relations, plants get carbon from air (Allen et al., 2020) and release it in soil in the form of exudates to stimulate soil biota (Badri and Vivanco, 2009). This biota may utilize different organic sources to build up SOC (Abdelhafez et al., 2018), including exudates to increase residual SOC. The combined treatments between organic manures (compost and biogas) and inorganic-N gave higher significant increases in soil 
residual organic carbon than the treatments that received $100 \%$ humic or fulvic acid. These results confirm that the most resistant organic amendments are not always recommended to increase the residual organic carbon in soil. Inducing microbial activities might be the optimum solution for increasing $\mathrm{C}$ sequestration in soil while lessen global warming threat. Using managed organic input, as a technique for fulfilling the requirements of $\mathrm{N}$ is probably more preferable than using the traditional organic amendments that resist microbial degradation such as humic substances or biochars (Abdelhafez et al., 2017; Bassouny and Abbas, 2019; Abdelhafez et al., 2020). Further studies are needed in this concern.

Results also reveal that the residual organic carbon significantly varied between the two soils of study (calcareous vs the non-calcareous one) (F=567.363, $P<0.001)$. This might occur because SOC is somewhat higher in the calcareous soil than in the non-calcareous one (see Table 1). The combination between the three factors were of significant effect on ROC $(\mathrm{F}=8.425, P<0.001)$. The highest increases in this concern occurred in the calcareous soil amended with biogas manure, which recorded approximately 4.5 folds higher ROC than the control treatment.

\section{Effect on Cation exchange capacity (CEC)}

Analysis of variance revealed that the values of soil CEC did not significantly change between the two soils of study $(\mathrm{F}=1.611, P=0.210)$ or even due to the source of organic amendment $(\mathrm{F}=0.952$, $P=0.333)$. However, soil CEC varied significantly in soil according to the type of the organic treatment $(\mathrm{F}=4.283, P<0.001)$. In this concern, the organic amendment, when applied solely or in the combinations between $\mathrm{FA} / \mathrm{HA}$ and mineral fertilizers, the highest CEC values were detected with no significant variations among these treatments (Table 6). Probably, humic acids (HAs) coated soil minerals (Ghabbour et al., 2004) and exhibited many functional acidic groups e.g. carboxylic acids, carbonyl groups and phenolic hydroxyl groups that increased soil CEC (Hankins et al., 2006; Majzik and Tombácz, 2007; Rashid et al., 2017). The combination between these three factors were of significant effect on soil CEC $(\mathrm{F}=2.814, P=0.018)$.

Table 6. Residual organic carbon and cation exchange capacity (CEC) of the sandy non-calcareous and calcareous soils under study as affected by the application of organic and mineral fertilizers, either solely or in different combinations (Treatments from $\mathrm{T}_{0}$ to $\mathrm{T}_{6}$ : see Table 4 )

\begin{tabular}{lcccc}
\hline \multicolumn{2}{c}{ Non-calcareous soil } & \multicolumn{2}{c}{ Calcareous soil } \\
\hline Treatment & Biogas manure & Compost & Biogas manure & Compost \\
\hline $\mathrm{T}_{0}$ & \multicolumn{3}{c}{ Residual organic carbon, g kg ${ }^{-1}$} & $4.76 \pm 0.30^{\mathrm{g}}$ \\
$\mathrm{T}_{1}$ & $2.20 \pm 0.58^{\mathrm{i}}$ & $2.20 \pm 0.58^{\mathrm{i}}$ & $4.76 \pm 0.30^{\mathrm{g}}$ & $3.90 \pm 0.20^{\mathrm{a}}$ \\
$\mathrm{T}_{2}$ & $7.31 \pm 0.19^{\mathrm{b}-\mathrm{d}}$ & $5.92 \pm 0.25^{\mathrm{ef}}$ & $9.98 \pm 0.30^{\mathrm{a}}$ & $3.70 \pm 0.17^{\mathrm{bc}}$ \\
$\mathrm{T}_{3}$ & $3.72 \pm 0.20^{\mathrm{gh}}$ & $8.00 \pm 0.48^{\mathrm{b}}$ & $7.60 \pm 0.60^{\mathrm{bc}}$ & $4.90 \pm 0.48^{\mathrm{f}}$ \\
$\mathrm{T}_{4}$ & $3.71 \pm 0.59^{\mathrm{gh}}$ & $3.31 \pm 0.55^{\mathrm{hi}}$ & $5.86 \pm 0.41^{\mathrm{f}}$ & $5.30 \pm 0.49^{\mathrm{b}-\mathrm{d}}$ \\
$\mathrm{T}_{5}$ & $3.19 \pm 0.45^{\mathrm{hi}}$ & $3.48 \pm 0.31 \mathrm{~h}$ & $7.31 \pm 0.38^{\mathrm{b}-\mathrm{d}}$ & $3.80 \pm 0.45^{\mathrm{b}-\mathrm{e}}$ \\
$\mathrm{T}_{6}$ & $3.25 \pm 0.27^{\mathrm{hi}}$ & $3.71 \pm 0.42^{\mathrm{gh}}$ & $7.02 \pm 0.28^{\mathrm{b}-\mathrm{e}}$ & $4.20 \pm 0.52^{\mathrm{c}-\mathrm{f}}$ \\
\hline & $3.07 \pm 0.31^{\mathrm{hi}}$ & $3.31 \pm 0.24^{\mathrm{hi}}$ & $6.67 \pm 0.34^{\mathrm{c}-\mathrm{f}}$ & \\
\hline $\mathrm{T}_{0}$ & Cation exchange capacity $(\mathrm{CEC})$ & $12.5 \pm 1.5^{\mathrm{e}}$ \\
$\mathrm{T}_{1}$ & $14.7 \pm 1.5^{\mathrm{a}-\mathrm{e}}$ & $14.7 \pm 1.0^{\mathrm{a}-\mathrm{e}}$ & $12.5 \pm 1.1^{\mathrm{e}}$ & $15.0 \pm 1.7^{\mathrm{a}-\mathrm{e}}$ \\
$\mathrm{T}_{2}$ & $15.0 \pm 1.2^{\mathrm{a}-\mathrm{e}}$ & $15.6 \pm 1.8^{\mathrm{a}-\mathrm{d}}$ & $12.0 \pm 1.6^{\mathrm{e}}$ & $13.8 \pm 1.7^{\mathrm{c}-\mathrm{e}}$ \\
$\mathrm{T}_{3}$ & $14.5+1.9^{\mathrm{b}-\mathrm{e}}$ & $15.5 \pm 1.9^{\mathrm{a}-\mathrm{d}}$ & $16.7 \pm 1.6^{\mathrm{a}-\mathrm{c}}$ & $13.8 \pm 1.0^{\mathrm{c}-\mathrm{e}}$ \\
$\mathrm{T}_{4}$ & $17.0 \pm 1.0^{\mathrm{ab}}$ & $16.3 \pm 1.3^{\mathrm{a}-\mathrm{c}}$ & $16.7 \pm 1.5^{\mathrm{a}-\mathrm{c}}$ & $14.9 \pm 1.2^{\mathrm{a}-\mathrm{e}}$ \\
$\mathrm{T}_{5}$ & $16.5 \pm 0.8^{\mathrm{a}-\mathrm{c}}$ & $12.7 \pm 1.0^{\mathrm{de}}$ & $17.5 \pm 0.8^{\mathrm{a}}$ & $14.3 \pm 1.1^{\mathrm{b}-\mathrm{e}}$ \\
$\mathrm{T}_{6}$ & $12.1 \pm 1.2^{\mathrm{a}-\mathrm{c}}$ & $16.1 \pm 1.1^{\mathrm{a}-\mathrm{c}}$ & $16.2 \pm 1.8^{\mathrm{a}-\mathrm{c}}$ & $16.0 \pm 1.6^{\mathrm{a}-\mathrm{c}}$ \\
\hline
\end{tabular}



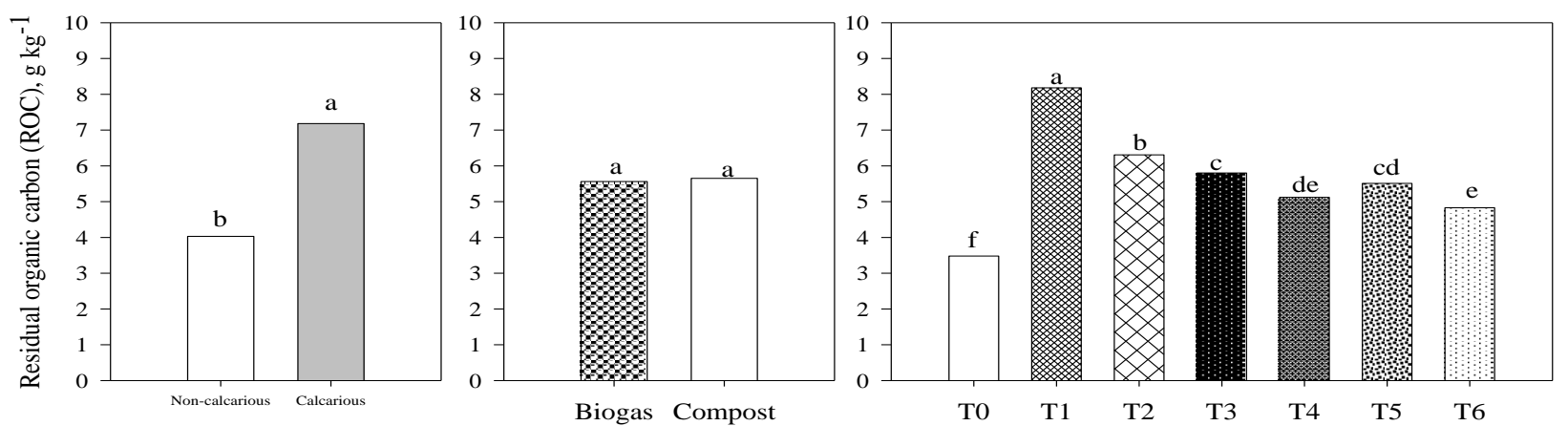

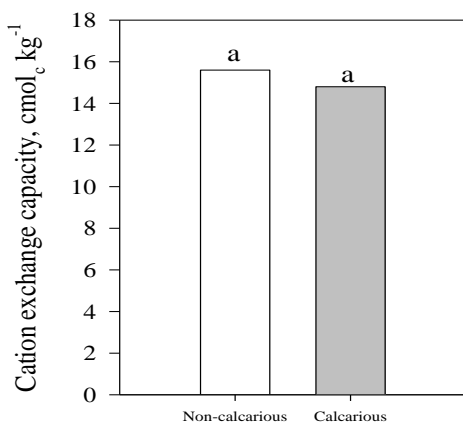

Soil Type

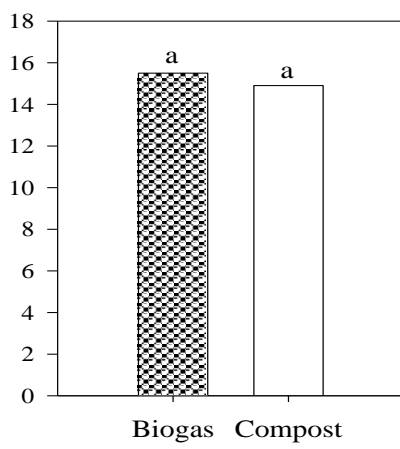

Organic source

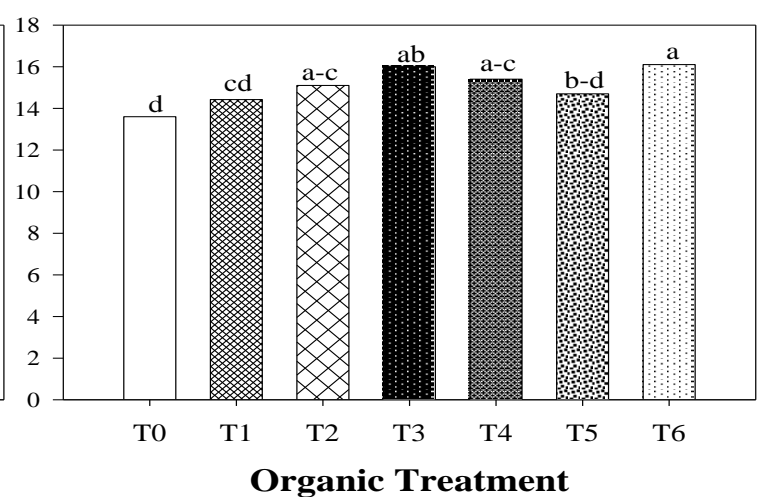

Fig. 2. Grand means of residual organic carbon and CEC of the sandy soils under study as affected by organic and mineral-N fertilizers, applied either solely or in different combinations treatments (Treatments from $\mathrm{T}_{0}$ to $\mathrm{T}_{6}$ : see Table 4 ).

\section{Soil pH}

Soil $\mathrm{pH}$ did not change significantly owing to the source of organic amendment $(\mathrm{F}=0.008, P=0.929)$. Likewise, organic treatments recorded no significant effect on soil $\mathrm{pH}(\mathrm{F}=0.253, P=0.956)$. These results did not agree with the findings of Mahmood $\boldsymbol{e t}$ al. (2017) who indicated that application of organic amendments, regardless of their nature, significantly decreased soil $\mathrm{pH}$. On the other hand, results obtained herein indicate that the $\mathrm{pH}$ values significantly varied between the two soils of study $(\mathrm{F}=7.850, P=0.007)$. This is probably due to the hydrolysis of calcium carbonate in the calcareous soil which accounted for such increases in soil $\mathrm{pH}$ according to the equation suggested by Al-Busaidi and Cookson (2003).

$$
\mathrm{CaCO}_{3} \text { (calcite) }+2 \mathrm{H}^{+} \leftrightarrow \mathrm{Ca}^{2+}+\mathrm{CO}_{2}+\mathrm{H}_{2} \mathrm{O}
$$

Interactions among the investigated three factors were also of no significant effect on soil $\mathrm{pH}$ ( $\mathrm{F}=0.883, P=0.513)$. These results sound reasonable in the calcareous soil where soil resist acidification according to Zhang et al. (2016); however, in the non-calcareous soil which is characterized by its low buffering capacity (Fest et al., 2005), some other factors may contribute to increase soil buffering capacity in our case. Probably, mineralization of soil organic matter neutralized most of soil acidity (Fujii et al., 2017).

Soil EC
Soil EC was significantly affected by each of the investigated organic sources $(\mathrm{F}=4.758, P=0.033)$ and soil type $(\mathrm{F}=43.959, P<0.001)$ as well as the organic treatment $(\mathrm{F}=3.538, P=0.005)$. The values of $\mathrm{EC}$ obtained in the calcareous soil were higher than the corresponding ones of the non-calcareous one (Table 7). Application of the organic amendments significantly decreased soil EC, except for the application of HA and FA acids, which gave significant increases in soil EC when compared with the non-amended control. The increases in soil EC owing to the application of these organic acids were more pronounced with the application of compost rather than biogas manure. This might occur because of the mineralization of soil nutrients during organic matter decomposition (Abdelhafez et al., 2018) and these nutrients were probably chelated in soluble forms (Elshony et al., 2019); thus soil EC increased significantly. Moreover, the EC values due to application of compost and its extracts were relatively higher than the corresponding values attained due to the biogas manure and its extracts. Interactions among the studied three factors were also of highly significant effect on soil EC $(\mathrm{F}=4.189$, $P=0.002)$. The highest increases in soil EC were attained in the calcareous soils amended with FA which was originated from biogas manure; while the lowest value was obtained in the same soil due to the application of biogas manure to satisfy $100 \%$ of Nneeds. 
Table 7. Soil pH and EC as affected by application of organic and mineral fertilizers, either solely or in different combinations (Treatments from $\mathrm{T}_{0}$ to $\mathrm{T}_{6}$ : see Table 4)

\begin{tabular}{|c|c|c|c|c|}
\hline & \multicolumn{2}{|c|}{ Non-calcareous } & \multicolumn{2}{|l|}{ Calcareous soil } \\
\hline & Biogas manure & Compost & Biogas manure & Compost \\
\hline \multicolumn{5}{|c|}{ Soil pH } \\
\hline $\mathrm{T}_{0}$ & $7.65 \pm 0.68^{\mathrm{a}}$ & $7.65 \pm 0.63^{\mathrm{a}}$ & $8.20 \pm 0.46^{\mathrm{a}}$ & $8.20 \pm 0.44^{\mathrm{a}}$ \\
\hline $\mathrm{T}_{1}$ & $7.94 \pm 0.90^{\mathrm{a}}$ & $7.56 \pm 0.81^{a}$ & $8.15 \pm 0.42^{\mathrm{a}}$ & $7.46 \pm 0.55^{\mathrm{a}}$ \\
\hline $\mathrm{T}_{2}$ & $7.83 \pm 0.68^{a}$ & $8.01 \pm 0.76^{\mathrm{a}}$ & $8.27 \pm 0.92^{\mathrm{a}}$ & $8.36 \pm 0.67^{\mathrm{a}}$ \\
\hline $\mathrm{T}_{3}$ & $7.56 \pm 0.90^{\mathrm{a}}$ & $8.00 \pm 1.02^{\mathrm{a}}$ & $8.43 \pm 0.55^{\mathrm{a}}$ & $8.07 \pm 0.65^{\mathrm{a}}$ \\
\hline $\mathrm{T}_{4}$ & $8.02 \pm 0.59^{a}$ & $7.86 \pm 0.40^{\mathrm{a}}$ & $8.19 \pm 0.63^{\mathrm{a}}$ & $8.34 \pm 0.47^{\mathrm{a}}$ \\
\hline $\mathrm{T}_{5}$ & $8.03 \pm 0.75^{\mathrm{a}}$ & $6.74 \pm 1.39^{\mathrm{a}}$ & $8.31 \pm 0.40^{\mathrm{a}}$ & $8.25 \pm 0.57^{\mathrm{a}}$ \\
\hline $\mathrm{T}_{6}$ & $7.44 \pm 1.21^{\mathrm{a}}$ & $8.45 \pm 0.46^{\mathrm{a}}$ & $8.23 \pm 0.42^{\mathrm{a}}$ & $8.00 \pm 1.02^{\mathrm{a}}$ \\
\hline \multicolumn{5}{|c|}{ Soil EC $\left(\mathrm{dS} \mathrm{m} \mathrm{m}^{-1}\right)$} \\
\hline $\mathrm{T}_{0}$ & $0.48 \pm 0.10^{\mathrm{d}-\mathrm{h}}$ & $0.48 \pm 0.02^{\mathrm{d}-\mathrm{h}}$ & $0.78 \pm 0.05^{\mathrm{cd}}$ & $0.78 \pm 0.06^{\mathrm{cd}}$ \\
\hline $\mathrm{T}_{1}$ & $0.49 \pm 0.03^{\mathrm{d}-\mathrm{h}}$ & $0.67 \pm 0.04^{\mathrm{c}-\mathrm{g}}$ & $0.42 \pm 0.45^{\mathrm{h}}$ & $0.75 \pm 0.26^{\mathrm{c}-\mathrm{f}}$ \\
\hline $\mathrm{T}_{2}$ & $0.73 \pm 0.04^{\mathrm{c}-\mathrm{g}}$ & $0.47 \pm 0.15^{\mathrm{d}-\mathrm{h}}$ & $0.77 \pm 0.02^{\mathrm{c}-\mathrm{e}}$ & $0.50 \pm 0.09^{\mathrm{d}-\mathrm{h}}$ \\
\hline $\mathrm{T}_{3}$ & $0.46 \pm 0.13^{\mathrm{f}-\mathrm{h}}$ & $0.49 \pm 0.15^{\mathrm{d}-\mathrm{h}}$ & $0.65 \pm 0.10^{\mathrm{c}-\mathrm{h}}$ & $1.26 \pm 0.12^{\mathrm{a}}$ \\
\hline $\mathrm{T}_{4}$ & $0.38 \pm 0.12^{\mathrm{h}}$ & $0.47 \pm 0.09^{\mathrm{d}-\mathrm{h}}$ & $0.77 \pm 0.07^{\mathrm{c}-\mathrm{e}}$ & $0.75 \pm 0.10^{\mathrm{c}-\mathrm{f}}$ \\
\hline $\mathrm{T}_{5}$ & $0.46 \pm 0.06^{\mathrm{f}-\mathrm{h}}$ & $1.16 \pm 0.08^{\mathrm{ab}}$ & $0.66 \pm 0.11^{\mathrm{c}-\mathrm{h}}$ & $0.73 \pm 0.08^{\mathrm{c}-\mathrm{g}}$ \\
\hline $\mathrm{T}_{6}$ & $0.64 \pm 0.13^{\mathrm{c}-\mathrm{h}}$ & $0.44 \pm 0.22^{\mathrm{gh}}$ & $1.16 \pm 0.26^{\mathrm{ab}}$ & $0.91 \pm 0.08^{\mathrm{bc}}$ \\
\hline
\end{tabular}
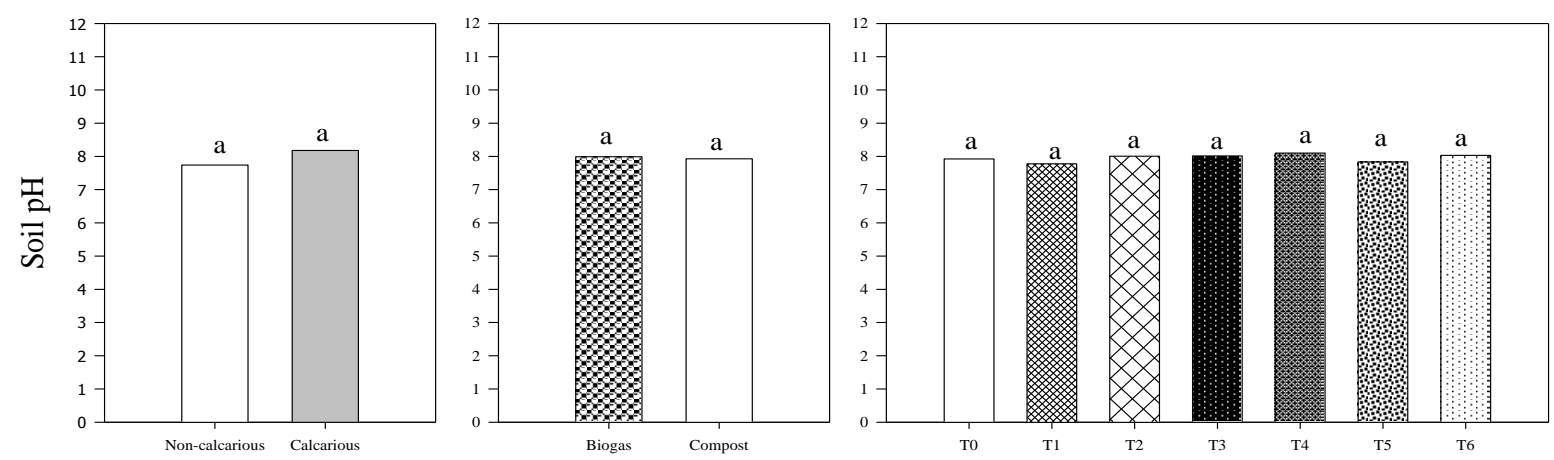

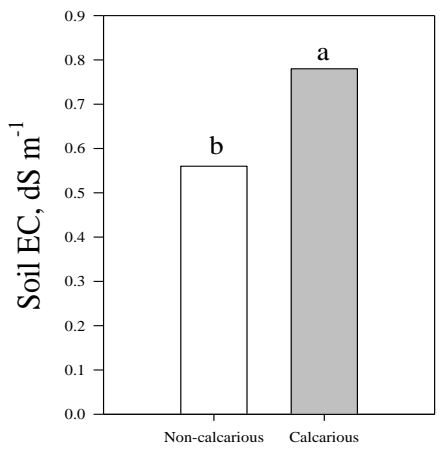

Soil Type

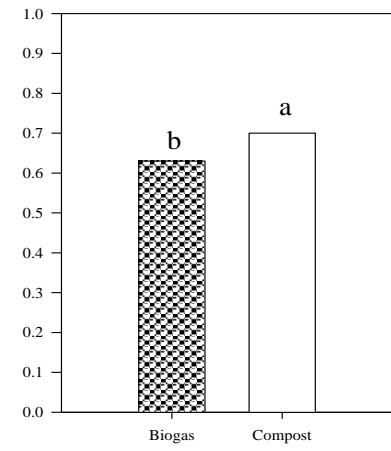

Organic source

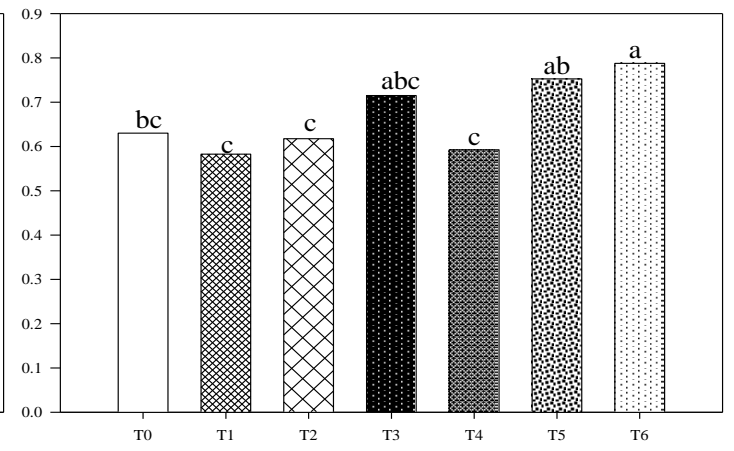

Organic Treatment

Fig 3. Grand means of soil $\mathrm{pH}$ and EC of the sandy non-calcareous and calcareous soils as affected by the application of organic and mineral fertilizers, either solely or in different combinations (Treatments from $\mathrm{T}_{0}$ to $\mathrm{T}_{6}$ : see Table 4)

Effect of organic amendments and their extracts on soil biota

Total counts of bacteria
Analysis of variance revealed that the source of the organic amendment $(\mathrm{F}=50.148, P<0.001)$ as well as the different organic treatments $(\mathrm{F}=19.960$, $P<0.001)$ had significant effects on total bacterial counts in soil while these counts did not significantly 
vary $(\mathrm{F}=2.873, P=0.096)$ between the two soils under investigation. Although, the total bacterial count was higher due to compost manure than due to biogas manure; nevertheless, the organic carbon content was higher in biogas manure than in compost (see Table 2). Also, biogas manure exhibited higher $\mathrm{C} / \mathrm{N}$ ratio than compost. Thus, the total bacterial counts were higher in soils that received biogas manure than those received compost (Fig.4). This carbon is used by soil biota as a source of energy (Farid $\boldsymbol{e t}$ al., 2018; Mohamed et al., 2021). Concerning the effect of the organic treatments, it was found that HA and FA treatments exhibited the highest increases in the total bacterial counts. On the other hand, no significant effects were found for the combination among these three factors on total bacterial counts in soil $(\mathrm{F}=1.035, P=0.413)$ and the means of the studied treatments are shown in Table 8.

\section{Total counts of fungi:}

Table 8 and Figure 4 reveal that the total counts of fungi did not vary significantly between the two soils (calcareous vs non-calcareous) under investigation $(\mathrm{F}=0.058, P=0.811)$; yet fungal counts were higher in soils amended with organics originated from biogas manure than the corresponding ones originated from compost $(\mathrm{F}=165.6, \quad P<0.001)$. Such increases might be attributed to the relatively higher contents of organic matter in biogas manure than in compost (see Table 2 ), which accelerated fungal growth. Fig 3 also shows that the organic treatment that induced the highest fungal growth was $50 \% \mathrm{HA}$, followed by FA treatments $(100 \%$ and $50 \%)$. The combination among the studied three factors recorded further significant effects on fungal counts in soil $(\mathrm{F}=2.625, P=0.026)$. In this concern, the highest increases were recorded in, whether the non-calcareous or calcareous soils, amended with HA originated from biogas manure. Generally, total bacterial and fungal counts were higher in soils amended with the different organic amendments than those not amended with organic manures or their extracts. These biota increased soil capacity to do many beneficial ecosystem roles (Moreno-Cornejo et al., 2014).

Table 8. Total counts of bacteria and fungi in soil as affected by organic and mineral fertilizers, applied either solely or in different combinations

\begin{tabular}{|c|c|c|c|c|}
\hline & Non-calcareous & & Cal carious soil & \\
\hline Treatment & Biogas manure & Compost & Biogas manure & Compost \\
\hline \multicolumn{5}{|c|}{ Total bacteria } \\
\hline $\mathrm{T}_{0}$ & $35.0 \pm 5.8^{\mathrm{h}-\mathrm{j}}$ & $35.0 \pm 5.8^{\mathrm{h}-\mathrm{j}}$ & $34.0 \pm 3.0^{\mathrm{ij}}$ & $34.0 \pm 2.95^{\mathrm{ij}}$ \\
\hline $\mathrm{T}_{1}$ & $50.0 \pm 1.9^{\mathrm{b}-\mathrm{e}}$ & $42.0 \pm 2.5^{\mathrm{e}-\mathrm{i}}$ & $55.0 \pm 3.8^{\mathrm{abc}}$ & $39.0 \pm 2.0^{\mathrm{g}-\mathrm{j}}$ \\
\hline $\mathrm{T}_{2}$ & $39.0 \pm 4.5^{\mathrm{g}-\mathrm{j}}$ & $31.0 \pm 2.8^{\mathrm{j}}$ & $44.0 \pm 3.9^{\mathrm{d}-\mathrm{h}}$ & $37.0 \pm 3.8^{\mathrm{h}-\mathrm{j}}$ \\
\hline $\mathrm{T}_{3}$ & $56.0 \pm 2.0^{\mathrm{ab}}$ & $35.0 \pm 4.8^{\mathrm{h}-\mathrm{j}}$ & $60.0 \pm 2.9^{\mathrm{a}}$ & $49.0 \pm 1.7^{\mathrm{b}-\mathrm{f}}$ \\
\hline $\mathrm{T}_{4}$ & $49.0 \pm 2.7^{\mathrm{b}-\mathrm{f}}$ & $42.0 \pm 4.2^{\mathrm{e}-\mathrm{i}}$ & $57.0 \pm 2.8^{\mathrm{ab}}$ & $53.0 \pm 4.5^{\mathrm{abc}}$ \\
\hline $\mathrm{T}_{5}$ & $54.0 \pm 9.5^{\mathrm{a}-\mathrm{c}}$ & $41.0+2.7^{\mathrm{f}-\mathrm{i}}$ & $49.0 \pm 1.7^{\mathrm{b}-\mathrm{f}}$ & $38.0 \pm 3.8^{\mathrm{h}-\mathrm{j}}$ \\
\hline $\mathrm{T}_{6}$ & $47.0 \pm 3.1^{\mathrm{c}-\mathrm{g}}$ & $51.0 \pm 2.4^{\mathrm{bd}}$ & $40.0 \pm 3.4^{\mathrm{g}-\mathrm{i}}$ & $42.0 \pm 5.2^{\mathrm{e}-\mathrm{i}}$ \\
\hline \multicolumn{5}{|c|}{ Total fungi } \\
\hline $\mathrm{T}_{0}$ & $18 \pm 3.7^{\mathrm{hi}}$ & $18 \pm 3.7^{\mathrm{hi}}$ & $26 \pm 1.3^{\mathrm{g}}$ & $26 \pm 1.2^{g}$ \\
\hline $\mathrm{T}_{1}$ & $38 \pm 1.4^{\mathrm{c}-\mathrm{f}}$ & $21+3.0^{\mathrm{gh}}$ & $33 \pm 3.7^{f}$ & $18 \pm 2.6^{\mathrm{hi}}$ \\
\hline $\mathrm{T}_{2}$ & $43 \pm 4.8^{\mathrm{bc}}$ & $19 \pm 3.2^{\mathrm{ghi}}$ & $38 \pm 3.7^{\text {cdef }}$ & $12 \pm 3.1^{\mathrm{i}}$ \\
\hline $\mathrm{T}_{3}$ & $40 \pm 4.5^{\mathrm{b}-\mathrm{e}}$ & $20 \pm 2.8^{\mathrm{gh}}$ & $51 \pm 2.9^{\mathrm{a}}$ & $15 \pm 1.8^{\mathrm{hi}}$ \\
\hline $\mathrm{T}_{4}$ & $46 \pm 3.1^{\mathrm{ab}}$ & $41 \pm 2.7^{\text {bcde }}$ & $47 \pm 4.5^{\mathrm{ab}}$ & $39 \pm 4.2^{c-f}$ \\
\hline $\mathrm{T}_{5}$ & $41 \pm 6.0^{\mathrm{b}-\mathrm{e}}$ & $34 \pm 3.3^{\text {ef }}$ & $44 \pm 5.8^{\mathrm{abc}}$ & $41 \pm 3.0^{\mathrm{b}-\mathrm{e}}$ \\
\hline $\mathrm{T}_{6}$ & $39 \pm 4.4^{\mathrm{c}-\mathrm{f}}$ & $42 \pm 3.0^{\mathrm{bcd}}$ & $37 \pm 4.1^{\mathrm{c}-\mathrm{f}}$ & $35 \pm 5.6^{\mathrm{d}-\mathrm{f}}$ \\
\hline
\end{tabular}



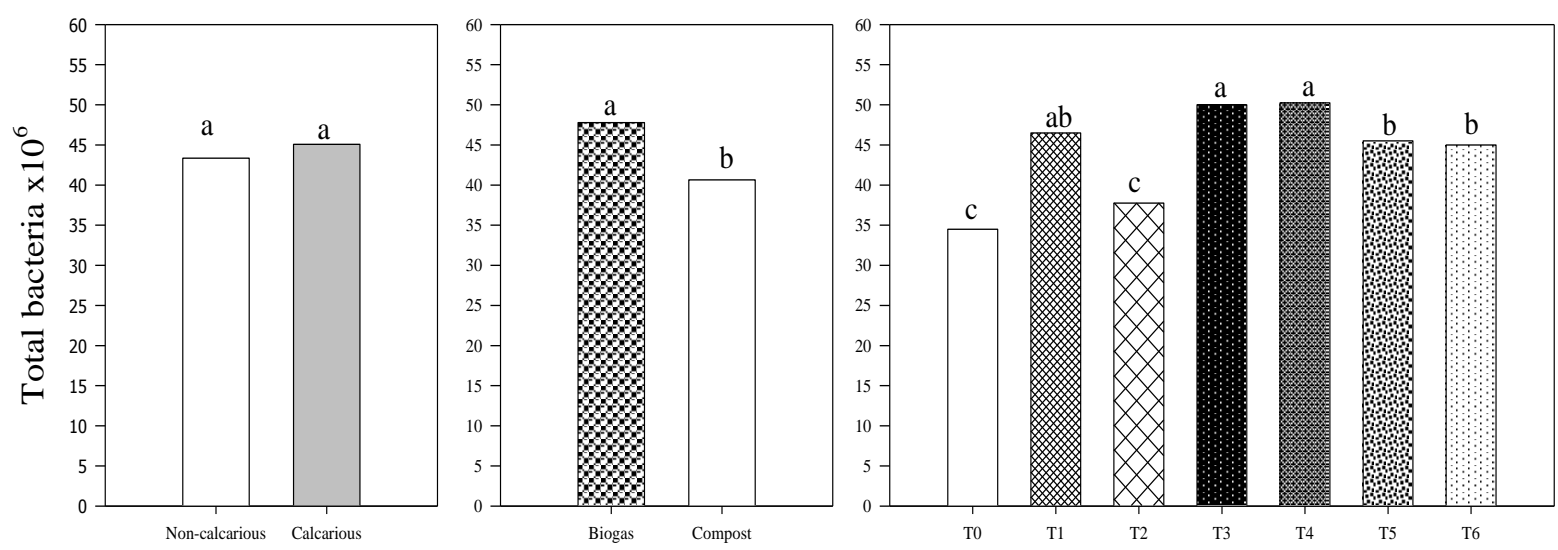

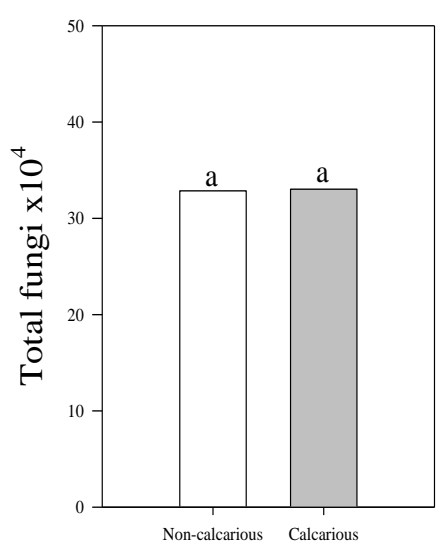

Soil Type

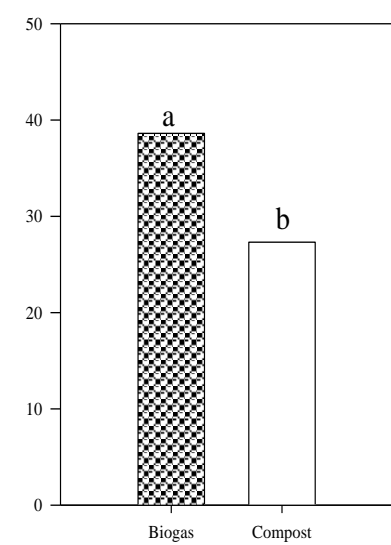

Organic source

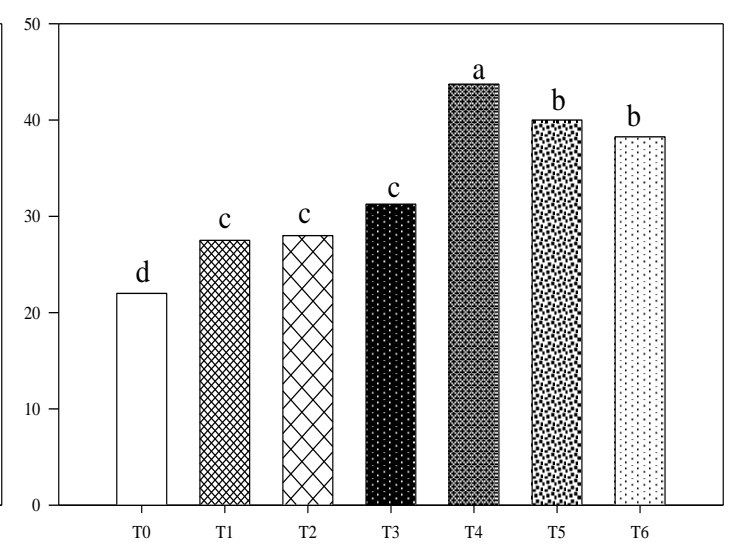

Organic Treatment

Fig.4. Grand means of total bacterial and fungal counts in sandy non-calcareous and calcareous soils as affected by organic and mineral-N fertilizers, applied either solely or in different combinations (Treatments $\mathrm{T}_{0}$ to $\mathrm{T}_{6}$ : see Table 4).

\section{Conclusion}

Application of organic amendments and their extracts (HA and FA ) recorded positive impacts on both soil chemical characteristics (except for soil $\mathrm{pH}$ ) and soil biota on the short run; yet, their effects were not detectable on soil bulk density. In this concern, humic substances recorded more positive consequences on soil biota and the chemical characteristics of the studied sandy soils (calcareous and non-calcareous ones) than the organic sources of these extracts did. On the other hand, the organic sources could stimulate soil biota to build up higher soil organic carbon contents beyond those retained after the application of the humic substances. The above findings support partly the first and the second hypotheses which indicate that organic amendments have positive impacts on soil biota which may in turn improve soil chemical characteristics. It seems that physical changes are potentially related to long term microbial activities and their byproducts.

\section{References}

Abbas, M.H.H., Ismail, AO.A., El-Gamal, M.A.H. and Salem, H.M. (2011) Integrated effect of mineral nitrogen, bio and organic fertilization on soybean productivity. Egypt. J. Biotechnol. 39, 43-63

Abdelhafez, A.A., Abbas, M.H.H., Attia, T.M.S., El Bably, W. and Mahrous, S.E. (2018) Mineralization of organic carbon and nitrogen in semi-arid soils under organic and inorganic fertilization, Environmental Technology \& Innovation, 9, 243-253, https://doi.org/10.1016/j.eti.2017.12.011.

Abdelhafez, A., Abbas, M.H.H. and Li, J. (2017) Biochar: the black diamond for soil sustainability, contamination control and agricultural production. In Huang, W.-J..(ed) Engineering Applications of Biochar, InTech Open pp 7-27 http://dx.doi.org/10.5772/intechopen.68803

Abdelhafez, A.A. ,Zhang, X., Zhou, L., Zou, G., Cui, N., Abbas, M.H.H. and Hamed, M.H. (2020) Introductory Chapter: Is Biochar Safe In: Abdelhafez, A.A.; Abbas, M.H.H. Applications of Biochar for Environmental Safety. IntechOpen, pp. 16.http://dx.doi.org/10.5772/intechopen.91996 
Al-Busaidi, A.S. and Cookson, P. (2003) Salinity-pH relationships in calcareous soils. Agricultural and Marine Sciences, 8(1):41-46

Allen, L.H., Kimball, B.A., Bunce, J.A., Yoshimoto, M., Harazono, Y., Baker, J.T., Boote, K.J. and White, J.W. (2020) Fluctuations of $\mathrm{CO}_{2}$ in FreeAir $\mathrm{CO}_{2}$ Enrichment (FACE) depress plant photosynthesis, growth, and yield, Agricultural and Forest Meteorology, 284, 107899, https://doi.org/10.1016/j.agrformet.2020.107899.

Badri, D. V. and Vivanco, J.M. (2009) Regulation and function of root exudates.Plant Cell Environ., 32,666-681. https:// doi.org/ 10.1111/ j.1365$\underline{\text { 3040.2009.01926.x }}$

Balesdent, J., Chenu, C. and Balabane, M. (2000) Relationship of soil organic matter dynamics to physical protection and tillage. Soil Till. Res. 53, 215-230.https://doi.org/10.1016/S01671987(99)00107-5

Bassouny, M. and Abbas, M. (2019). Role of biochar in managing the irrigation water requirements of maize plants: the pyramid model signifying the soil hydro-physical and environmental markers. Egyptian Journal of Soil Science, 59(2), 99-115. https://doi.org/10.21608/ejss.2019.9990.1252

Blankinship, J.C. and Schimel, J.P. (2018) Biotic versus Abiotic Controls on Bioavailable Soil Organic Carbon. Soil Systems. 2(1):10. https://doi.org/10.3390/soilsystems20100 $\underline{10}$

Brye, K.R., Slaton, N.A., Norman, R.J. and Savin, M. C. (2005)Short-term Effects of Poultry Litter Form and Rate on Soil Bulk Density and Water Content,Communications in Soil Science and Plant Analysis35:15-16,23112325,https://doi.org/10.1081/LCSS-200030655

Chen, Y. and Schnitzer, M. (1978) The surface tension of aqueous solution of soil humic substances. Soil Sci.,125 , $7-15$.

Diacono, M. and Montemurro F. (2011) LongTerm Effects of Organic Amendments on Soil Fertility. In: Lichtfouse E., Hamelin M., Navarrete M., Debaeke P. (eds) Sustainable Agriculture Volume 2. Springer, Dordrecht. https://doi.org/10.1007/978-94-007-0394-0_34

Elcossy, S.A.E., Abbas, M.H.H., Farid, I.M., Beheiry, G.Gh., Abou Youssef,M.F., Abbas,H.H., Abdelhafez, A.A. and Mohamed, I. (2020) Dynamics of soil organic carbon in Typic Torripsamment soils irrigated with raw effluent sewage water. Environ Sci Pollut Res, 27, 81888198. doi: 10.1007/s11356-019-07526-4

Elshony, M., Farid, I., Alkamar, F., Abbas, M., Abbas, H. (2019). Ameliorating a sandy soil using biochar and compost amendments and their implications as slow release fertilizers on plant growth. Egyptian Journal of Soil Science, 59(4), 305-322.

https://doi.org/10.21608/ejss.2019.12914.1276
Fang, C., Smith, P., Moncrieff, J. and Smith, J.U.(2005) Similar response of labile and resistant soil organic matter pools to changes in temperature. Nature 433, 57-59.

https://doi.org/10.1038/nature03138

Farid, I.M., Abbas, M.H.H., Beheiry, G.Gh.S. and Elcossy, S.A.E. (2014) Implications of organic amendments and tillage of a sandy soil on its physical properties and C-sequestration as well as its productivity of wheat and maize grown thereon. Egypt. J. Soil Sci, 54 (2), 177-194. https://doi.org/10.21608/ejss.2014.132

Farid, I.M., Abbas, M.H.H. and El-Ghozoli, A. (2018) Implications of humic, fulvic and $\mathrm{K}$ humate extracted from each of compost and biogas manure as well as their teas on faba bean plants grown on Typic Torripsamments and emissions of soil CO2. Egypt. J. Soil Sci 58 (3), 275-298. https://doi.org/10.21608/ejss.2018.4232.1183

Fest, E.P.M., Temminghoff, E.J.M. Griffioen, J. and Van Riemsdijk, W.H. (2005) Proton buffering and metal leaching in sandy soils. Environmental Science \& Technology 39(20), 7901-7908. https://doi.org/10.1021/es0505806

Fujii, K., Hayakawa, C., Panitkasate, T., Maskhao, I., Funakawa, S., Kosaki, T. and Nawata, E. (2017) Acidification and buffering mechanisms of tropical sandy soil in northeast Thailand, Soil Till Res, 165, 80-87, https://doi.org/10.1016/j.still.2016.07.008.

Gerke, J. (2018) Concepts and misconceptions of humic substances as the stable part of soil organic matter: A review. Agronomy 8, 76. https://doi.org/10.3390/agronomy8050076

Ghabbour, E.A., Davies, G., Goodwillie, M.E., O'Donaugh, K. and Smith, T.L. (2004) Thermodynamics of peat-, plant-, and soilderived humic acid sorption on kaolinite. Environ. Sci. Technol. 38, 12, 33383342. https://doi.org/10.1021/es0352101

Goebel, M.-O., Woche, S.K. and Bachmann, J. (2009) Do soil aggregates really protect encapsulated organic matter against microbial decomposition? Biologia. 64, 443448.https://doi.org/10.2478/s11756-009-0065-Z

Grinhut, T., Hadar, Y.and Chen, Y. (2007) Degradation and transformation of humic substances by saprotrophic fungi: processes and mechanisms. Fungal Biol. Rev, 21, 179-189. https://doi.org/10.1016/j.fbr.2007.09.003

Guo, Z., Han, J., Xu, Y., Lu, Y., Shi, C., Ge, L., Cao, T. and Li, J. (2019) The mineralization characteristics of organic carbon and particle composition analysis in reconstructed soil with different proportions of soft rock and sand. PeerJ, 7, e7707. https://doi.org/10.7717/peerj.7707

Hankins, N.P., Lu, N. and Hilal, N. (2006) Enhanced removal of heavy metal ions bound to humic acid 
by polyelectrolyte flocculation, Separation and Purification Technology, 51 (1), 48-56, https://doi.org/10.1016/j.seppur.2005.12.022.

Hao, X.H., Liu, S.L., Wu, J.S., Hu, R.G., Tong, C.L. and Su, Y.Y.(2008) Effect of long-term application of inorganic fertilizer and organic amendments on soil organic matter and microbial biomass in three subtropical paddy soils. Nutr Cycl Agroecosyst 81, 17-24. https://doi.org/10.1007/s10705-007-9145-Z

Hemmat, A., Aghilinategh, N., Rezainejad, Y. and Sadeghi, M. (2010) Long-term impacts of municipal solid waste compost, sewage sludge and farmyard manure application on organic carbon, bulk density and consistency limits of a calcareous soil in central Iran, Soil and Tillage Research, $108 \quad$ (1-2), 43-50, https://doi.org/10.1016/j.still.2010.03.007.

Klute, A. (1986) Part 1. Physical and mineralogical methods.ASA-SSSA-Agronomy,

Madison, Wisconsin USA.

Kononova, M. M. (1966)Soil Organic Matter. Pergmon Press, Oxford, London, Edinburgh, New York.

Kumari, K., Prasad, J., Solanki, I. S. and Chaudhary, R. (2018). Long-term effect of crop residues incorporation on yield and soil physical properties under rice - wheat cropping system in calcareous soil. Journal of soil science and plant nutrition, 18(1),

27-

40. https://dx.doi.org/10.4067/S071895162018005000103

Lipczynska-Kochany, E. (2018A) Effect of climate change on humic substances and associated impacts on the quality of surface water and groundwater: A review, Science of The Total Environment, 640-641, 1548-1565, https://doi.org/10.1016/j.scitotenv.2018.05.376.

Lipczynska-Kochany, E. (2018B) Humic substances, their microbial interactions and effects on biological transformations of organic pollutants in water and soil: A review, Chemosphere, 202, 420-437,

https://doi.org/10.1016/j.chemosphere.2018.03.10 $\underline{4}$.

Liu, M., Hu, F., Chen, X., Huang, Q., Jiao, J., Zhang, B. and Li, H. (2009) Organic amendments with reduced chemical fertilizer promote soil microbial development and nutrient availability in a subtropical paddy field: The influence of quantity, type and application time of organic amendments, Applied Soil Ecology, 42 (2): 166175, https://doi.org/10.1016/j.apsoil.2009.03.006.

Mahmood, F., Khan, I., Ashraf, U., Shahzad, T., Hussain, S., Shahid, M., Abid, M. and Ullah, S.. (2017). Effects of organic and inorganic manures on maize and their residual impact on soil physico-chemical properties. Journal of soil science and plant nutrition, 17(1), 22-32.
https://dx.doi.org/10.4067/S071895162017005000002

Mohamed, I., Bassouny, M.A., Abbas, M.H.H., Ming, Z., Cougui, C., Fahad, S., Saud, S., Khattak, J.Z.K., Ali, S., Salem, H., Azab, A. and Ali, M. (2021) Rice straw application with different water regimes stimulate enzymes activity and improve aggregates and their organic carbon contents in a paddy soil, Chemosphere, 274 , 129971, https://doi.org/10.1016/j.chemosphere.2021.1299 $\underline{71}$

Majeed, A., Muhammad, Z. and Ahmad, H. (2018) Plant growth promoting bacteria: role in soil improvement, abiotic and biotic stress management of crops. Plant Cell Rep 37, 15991609. https://doi.org/10.1007/s00299-018-2341-2

Majzik, A. and Tombácz, E. (2007) Interaction between humic acid and montmorillonite in the presence of calcium ions I. Interfacial and aqueous phase equilibria: Adsorption and complexation, Organic Geochemistry, 38 (8), 1319-1329,

https://doi.org/10.1016/j.orggeochem.2007.04.00 3.

Moreno-Cornejo, J., Zornoza, R. and Faz, A. (2014) Carbon and nitrogen mineralization during decomposition of crop residues in a calcareous soil, Geoderma, 230-231, 58-63, https://doi.org/10.1016/j.geoderma.2014.03.024.

Nardi, S., Ertani, A. and Francioso, O. (2017) Soilroot cross-talking: The role of humic substances. J. Plant Nutr. Soil Sci., 180: 5-13. https://doi.org/10.1002/jpln.201600348

Rashid, M., Price, M.T., Pinilla, M.Á.G. and O'Shea, K.E. (2017) Effective removal of phosphate from aqueous solution using humic acid coated magnetite nanoparticles, Water Research, 123, 353-360, https://doi.org/10.1016/j.watres.2017.06.085.

Reinhold, B.; Hurek, T. and Fendrik, L. (1985)Strain specific chemotoxis of Azospirillum spp. $J$. Bacteriol., 162: 190 - 195.

Sanchez-Monedero, M. A., Roid, A., Cegarra, J., Bernal,M.P. and Paredes, C. (2002) Effects of HCL-HF purification treatment on chemical composition and structure of humic acids. Eur. J. Soil Sci., 53, 375 - 381.https://doi.org/10.1046/ j.1365-2389.2002.00464.x

Scotti, R, Bonanomi, G, Scelza, R, Zoina, A. and Rao, M.A. (2015). Organic amendments as sustainable tool to recovery fertility in intensive agricultural systems. Journal of soil science and plant nutrition, 15(2), 333-352. https://dx.doi.org/10.4067/S071895162015005000031

Sparks, D.L., Page, A.L., Helmke, P.A., Loeppert, R.H., Soltanpour, P.N., Tabatabai, M.A., Johnston, C.T. and M.E. Sumner (1996) Methods 
of Soil Analysis Part 3-Chemical Methods, 5.3. SSSA Book Series, Madison, WI.

Susilawti, K.,Ahmed, O.H., Muhamad, A.B.N. and Khanif, M.Y. (2007) Effects of extraction and fractionation period on the yield of a tropical peat soil (Hemists) humic acids. Am. J. Agric. Biol. Sci., 2(3), 2020 - 205.https://doi.org/10.3844/ ajabssp.2007.202.205

Tayyab, M., Islam, W., Lee, C.G., Pang, Z., Khalil, F., Lin, S., Lin, W. and Zhang, H. (2019) Shortterm effects of different organic amendments on soil fungal composition. Sustainability 11, 198. https://doi.org/10.3390/su11010198

Thakur, M.P., Reich, P.B., Hobbie, S.E., Stefanski, A., Rich, R., Rice, K.E., Eddy, W.C. and Eisenhauer, N.(2018) Reduced feeding activity of soil detritivores under warmer and drier conditions. Nature Clim Change 8, 75-78. https://doi.org/10.1038/s41558-017-0032-6

Tobiašová, E., Barančíková, G., Gömöryová, E., J., M., Skalský, R., Halas, J., Koco, Š.,Tarasovičová, Z., Takáč, J. and Špaňo, M. (2016) Labile forms of carbon and soil aggregates. Soil Water Res. 11, 259-266.https://doi.org/10.17221/182/2015-SWR

Urra, J., Alkorta, I. and Garbisu, C. (2019) Potential benefits and risks for soil health derived from the use of organic amendments in agriculture. Agronomy 9,

542. https://doi.org/10.3390/agronomy9090542

Wei, W., Yan, Y., Cao, J., Christie, P., Zhang, F. and Fan, M. (2016) Effects of combined application of organic amendments and fertilizers on crop yield and soil organic matter: An integrated analysis of long-term experiments, Agric Ecosyst Environ, 225, 86-92, https://doi.org/10.1016/j.agee.2016.04.004.

Williams, H., Colombi, T. and Keller, T. (2020)The influence of soil management on soil health: An on-farm study in southern Sweden. Geoderma360, 114010, https://doi.org/10.1016/j.geoderma.2019.114010

Zhang, L., Chen, X., Xu, Y., Jin, M. and Ye, X. (2020) Soil labile organic carbon fractions and soil enzyme activities after 10 years of continuous fertilization and wheat residue incorporation. Sci Rep 10, 11318. https://doi.org/10.1038/s41598-020-68163-3

Zhang, Y., Zhang, S., Wang, R., Cai, J., Zhang, Y., Li, H., Huang, S. and Jiang, Y. (2016) Impacts of fertilization practices on $\mathrm{pH}$ and the $\mathrm{pH}$ buffering capacity of calcareous soil, Soil Sci Plant Nutr, 62(5-6), 432-

439, https://doi.org/10.1080/00380768.2016.1226 $\underline{685}$ 
التداعيات قصيرة الأجل لإضافة أنواع مختلفة من المحسنات العضوية ومستخلصاتها للأراضي الرمليه( الجيريه وإلغير جيريه) علي النشاط الحيوي، والخواص الطبيعية والكيميائية للتربه

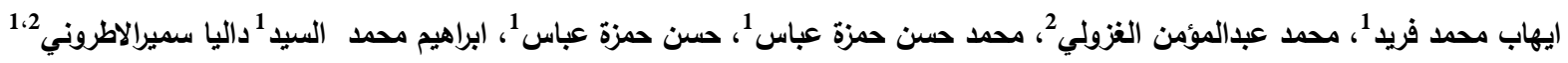

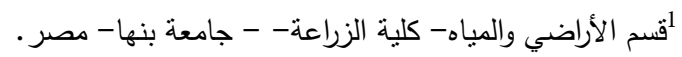
2² قسم الميكروبيولوجيا الزراعية- معهد بحوث الأراضى و المياهو البيئة- مركز البحوث الزراعية- الجيزة- مصر .

تعتبر إضافة المواد العضوية إلي أراضي المناطق القاحلة وشبه القاحلة ذات تأثبر ايجابي على كل من خصائص التربة ونثاط الكائنات الحية النامي بها، مع العلم أن معدلات تحلل هذه المركبات العضوية في هذه المناطق مرتفعة ، أما إضافة المواد الدبالية، والتي تعتبر مواد

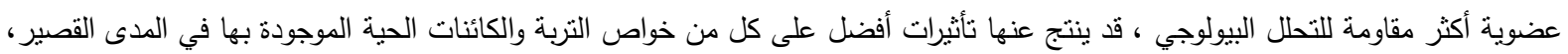

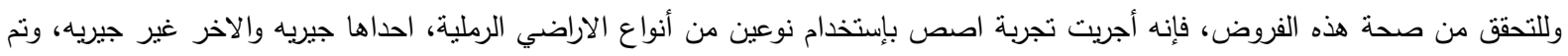

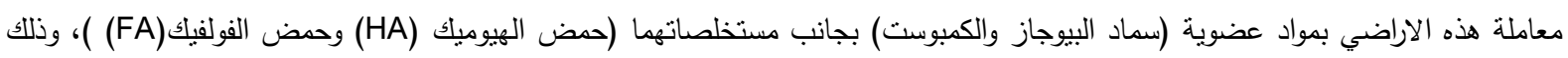
بمعدل 36 كجم نتروجين/للهكتار، والتي تكافؤ الجرعة الجرعة التتشيطية الموصي بها لنبات الفول، وقد شملت التجربة ايضا معاملة الكنترول والتي تمت اضافة النتروجين اليها علي صورة كبريتات امونيوم، ثم تمت زراعة الاصص بذور الفول الملحقه بالعقدين لددة 80 يومًا، وكان

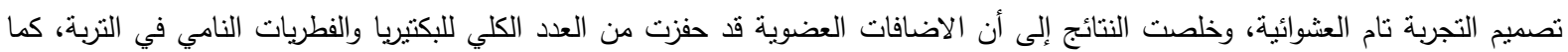

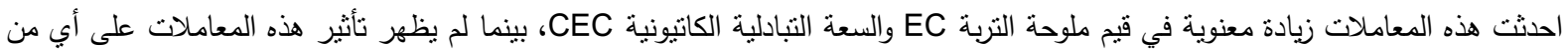
الكتافة الظاهرية للنزبة أودرجة حموضتها، واظهرت النتائج ايضا ان اضافة المستخلصات العضوية فد احدثت زيادات اكبر في اعداد البكتريا والفطريات عن نلك المتحصل عليها في حالة اضافة المحسنات العضوية نفسها، كما احذت تغيرات افضل في خواص التربة عن المتحصل عليها

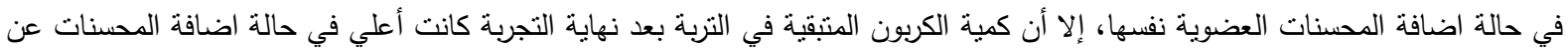

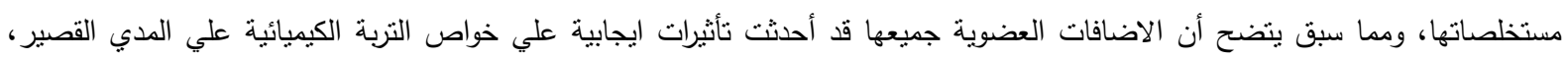
خاصة مستخلصات الاسمدة العضوية، بينما كانت الخواص الطبيعية مرتبطة في الغالب بالأنثطة الميكروبية طويلة الددى. 